\title{
Clay Minerals Channels Identification in the Tindikala-Boutou Area (Eastern-Cameroon) along the Kadey River Using Direct Current (DC) Method
}

\author{
Daniel Hervé Gouet ${ }^{1 *}$, Arsène Meying², Stéphane Patrick Assembe ${ }^{3}$, \\ Théophile Ndougsa-Mbarga ${ }^{4}$ \\ ${ }^{1}$ Department of Petroleum and Gas Explorations, Institute of Mines and Petroleum Industries, University of \\ Maroua, Maroua, Cameroun \\ ${ }^{2}$ Department of Applied Geophysics, Geology and Mining Exploitation College, University of Ngaoundéré, \\ Ngaoundéré, Cameroun \\ ${ }^{3}$ Department of Physics, Faculty of Science, University of Yaounde I, Yaoundé, Cameroon \\ ${ }^{4}$ Department of Physics, Advanced Teacher's Training College, University of Yaounde I, Yaoundé, Cameroon \\ Email: "gouetdanyl@yahoo.fr
}

Received 27 June 2015; accepted 23 August 2015; published 26 August 2015

Copyright (C) 2015 by authors and Scientific Research Publishing Inc.

This work is licensed under the Creative Commons Attribution International License (CC BY).

http://creativecommons.org/licenses/by/4.0/

\section{(c) (i) Open Access}

\section{Abstract}

To achieve the current study, geoelectrical surveys along six (06) profiles of $4 \mathrm{~km}$ long in a $100 \mathrm{~m}$ $\times 200 \mathrm{~m}$ grid defined according to the triangulation principle in the Tindikala-Boutou (EasternCameroon) area along the Kadey River have been made through electrical sounding and profiling following Schlumberger array. The instrument is the resistive meter Syscal Junior 48 (IRIS Instrument). The data have been processed and modelled with Res2Dinv and Winsev softwares, and then interpolated with Surfer software. Investigation method used is the Direct Current (DC) method. Interpretations and analyses of results from the investigation method highlight weak zones or conductive discontinuities. The latter has been identified as shear zones within granitic structures of the Precambrian basement, according to the geologic and tectonic background of the area. The structural trend of these shear zones is E-W approximately. The mineralization characterized by conductive zones proves the presence of clay minerals disseminated in weathered quartz vein, which cross the shear zones. The intense activities of gold washers encountered in the studied area are able to attest the presence of clay minerals concentrations.

\footnotetext{
*Corresponding author.
}

How to cite this paper: Gouet, D.H., Meying, A., Assembe, S.P. and Ndougsa-Mbarga, T. (2015) Clay Minerals Channels Identification in the Tindikala-Boutou Area (Eastern-Cameroon) along the Kadey River Using Direct Current (DC) Method. Journal of Geoscience and Environment Protection, 3, 123-133. http://dx.doi.org/10.4236/gep.2015.36018 


\section{Keywords}

\section{Geoelectrical Surveys, Direct Current Method, Resistivity, Shear Zones, Clay Minerals}

\section{Introduction}

The reliability of any geophysical exploration result is supported by the geological background assessment of a given area, no matter its purpose. In accordance with this, a geoelectrical investigation has been made in the Tindikala-Boutou village of the Ngoura subdivision (Eastern-Cameroon). The approach consists in collecting apparent resistivity data using the Direct Current Schlumberger's geoelectrical investigation (sounding and profiling). Data will be processed with Res2Dinv, Winsev and Surfer softwares. Results, given as pseudo sections of resistivity, resistivity maps will be able to plot tectonic unevenness of the area under study and also to characterize the associated mineralization. The geological sections realized through the interpretation of electrical soundings will bring out the correlation between the resistivity data and the geological background of the studied area.

\section{Geological and Tectonic Setting}

The study area (Tindikala-Boutou village) is located in the Ngoura subdivision in the heart of the East Cameroon's region. Its easting stretches from 426,000 $\mathrm{m}$ to 437,800 $\mathrm{m}$ and the northing from 548,750 $\mathrm{m}$ to 557,750 $\mathrm{m}$ following UTM33 WGS84 system (Figure 1 and Figure 2).
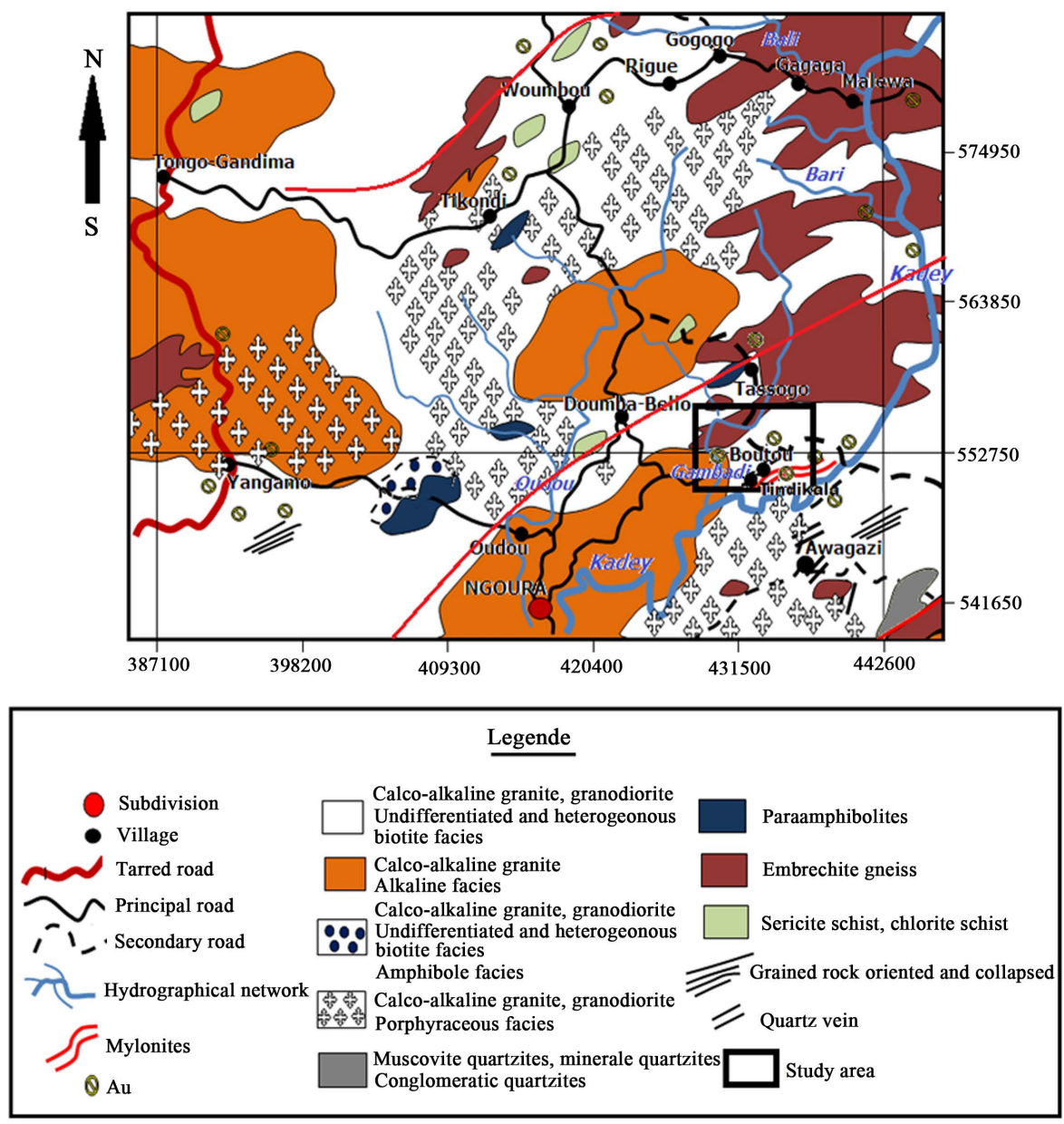

Figure 1. Geological map of the study area. 


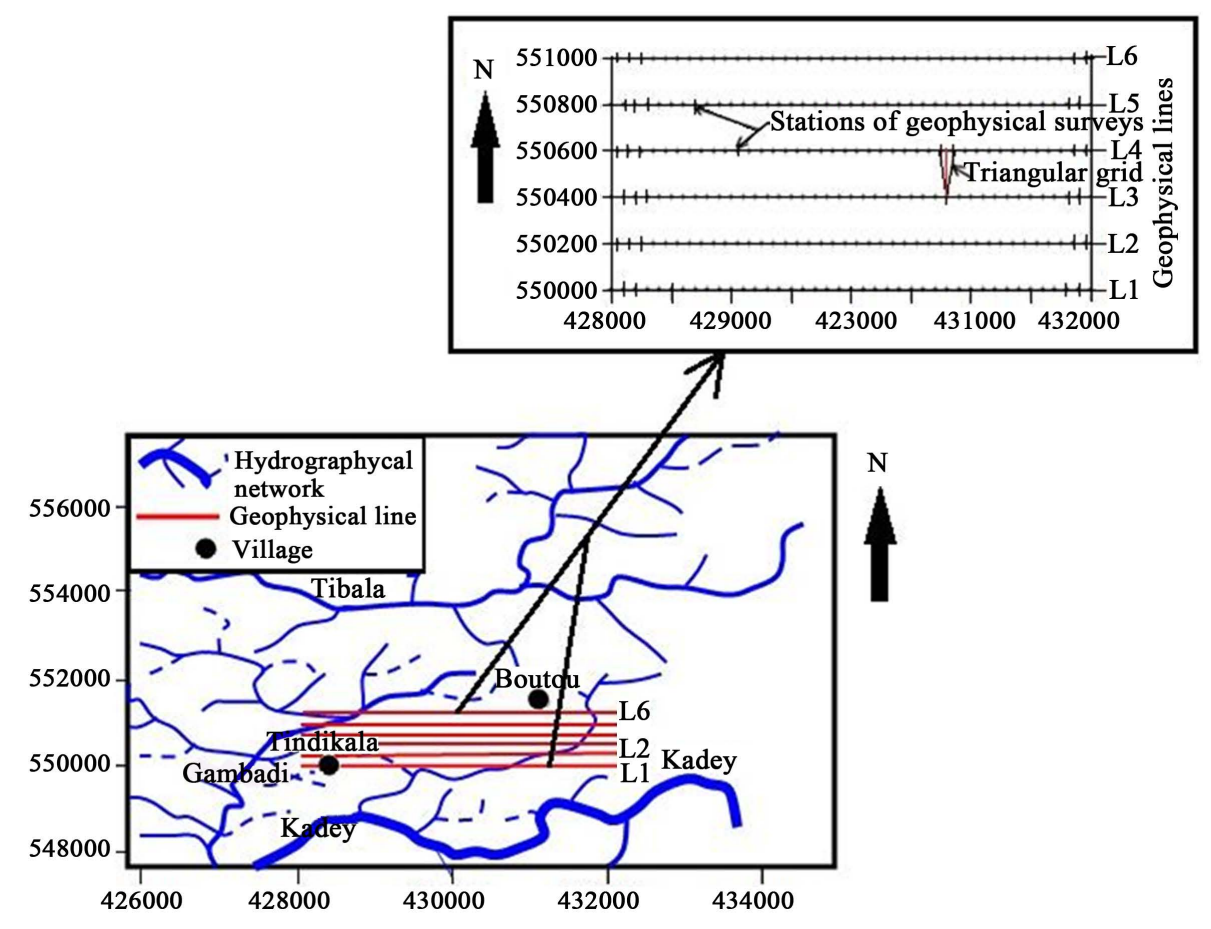

Figure 2. Profiles localization map in the study area.

The Ngoura area is located in the transition zone between the Pan African domain and the Congo Craton [1] [2], in the northern edge of the Cameroon faults' zone. This region of Cameroon is essentially made up of a Precambrian basement comprising metamorphic and magmatic rocks [3]-[5]. These are Precambrian rocks which sometimes outcrop. These are mainly granites and migmatites rejuvenated during the panafrican event. The area is mainly made up of (Figure 1) [6] [7]:

- Biotite and muscovite quartzites, sericitic muscovite and conglomeratic quartzites, chloritic and sericitic schists, paraamphibolites, orthogneisses, biotite gneisses and, pegmatites and quartz veins constituting the precambrian basal complex aged between 2.5 and 1.8 billion years.

- Plutonic and metamorphic formations made up of calc-alkaline granites with a porphyroic and alkali facies; granodiorites and syenites containing heterogeneous and undifferentiated biotite facies; quartz-diorites; micaschists, migmatites and embrechite gneisses.

- The main sedimentary rocks encountered are sandstones, sand, marl, limestones and, Paleozoic and Mesozoic conglomerates.

The tectonic facts revealed that, the study area is characterized by four deformations phases D1-D4 [8]. The observed tectonic lines are directed SW-NE below, and turned to be SE-NW above the $4 \mathrm{~N}$ parallel (Figure 1). Previous geophysical studies [9] [10] have shown evidence of some buried faults directed W-E and have confirmed tectonic nappes with a southern vergency. According to Olinga et al. (2010), the Pan-African deformation affecting the study area which appertains to the southern segment of the Neoproterozoic fold belt of Central Africa in Cameroon, is controlled by thrust tectonics and late strike-slip shear zones: the thrusting of the Pan-African Nappe over the Congo Craton (D2 deformation phase) is followed by a strike-slip shearing trending ENEWSW (D3 deformation phase). During these stages deforming conditions were ductile to brittle-ductile. The dominant structural features of the D3 phase are penetrative foliation steeply dipping $\mathrm{N}$ or $\mathrm{S}$, an associate ENEWSW stretching lineation, and an N-S to NE-SW folding. Deformation criteria in the distinguished rock units indicate dextral sense of shear. A dextral trans-pressional model is assumed by Olinga et al. (2010) to explain the observed thrust and shear movements.

\section{Method}

The resistivity is a suitable parameter in characterizing the nature and the weathering of materials [11]. Hence 
electrical prospecting methods have been used for a long time in geological and geotechnical engineering. These both qualitative and quantitative methods are based on the Ohm law [11]. They consist in the injection of a direct current in the ground and the measurement of the electrical potential which enables to obtain the true resistivity of encountered formations. In our study area, while considering the geological setting, Schlumberger sounding and profiling methods have been used to determine: the thickness, the lateral extension and the nature of formations encountered along a profile; and to highlight the geometry of geological bodies related to contrasted electrical characteristics [12].

Field electrical methods (D.C.) consist in injecting an electrical current in the ground between two electrodes A and B (Figure 3), and then, measuring the induced potential drop between two so-called potential electrodes $\mathrm{M}$ and $\mathrm{N}$ [12]. For the current intensity is known and the potential drop measured, it is therefore possible to determine the ground apparent resistivity. This apparent resistivity depends on the current and potential electrodes array. The apparent resistivity $\rho_{a}$ (Rho) can be expressed function of the potential drop and the current intensity [13]:

$$
\rho_{a}=K\left(V_{M N} / I_{A B}\right)
$$

where $\rho_{a}$ is in $\mathrm{Ohm} \cdot \mathrm{m}$, and $K$ (in $\mathrm{m}$ ) is the geometric factor depending on the electrodes' array which is given by the Formulae (2) below.

$$
K=2 \pi\left(A M^{-1}-A N^{-1}-B M^{-1}+B N^{-1}\right)
$$

$-V_{M N}$ : potential drop between electrodes $M$ and $N$, in $\mathrm{mV}$;

$-I_{A B}$ : electric current injected between electrodes $A$ and $B$, in $\mathrm{mA}$.

For the Schlumberger symmetrical configuration (Figure 3), the apparent resistivity $\rho_{a}$ is given by Equation (3) as follow [14]:

$$
\rho_{a}=\pi / 4\left(A B^{2} V_{M N} / M N \cdot I_{A B}\right)
$$

This resistivity value enables to characterize a formation in the point (o) or station (Figure 3 ). The resistivity of an earth's material depends essentially on the humidity and the clay proportion in a given volume of that material [15]. While clay and water fill in any vacuum in a rock, one assumes that the resistivity is function of parameters such as fracturing, fractures and fissures clay filling in, porosity, the clayey clogging of alluvium [11] [15].

\section{Material and Data Acquisition}

For a suitable coverage of the study area, data have been collected through 236 VES (vertical electrical sounding) along six (06) profiles of $4 \mathrm{~km}$ long in a $100 \mathrm{~m} \times 200 \mathrm{~m}$ grid, defined according to the triangulation principle (Figure 2). This grid has been designed according to the topographic data of the area whose coordinates have been expressed in UTM33 WGS84. The acquisition data is made by combining electrical sounding and profiling following the Schlumberger configuration along a profile (Figure 3). The AB maximum length was held at 600 $\mathrm{m}$ to detect desired lithological formations at an approximate depth between 114 and 130 meters [16]. To avoid miscellaneous due to formations' anisotropies, sounding and profiling surveys were E-W oriented (Figure 2).

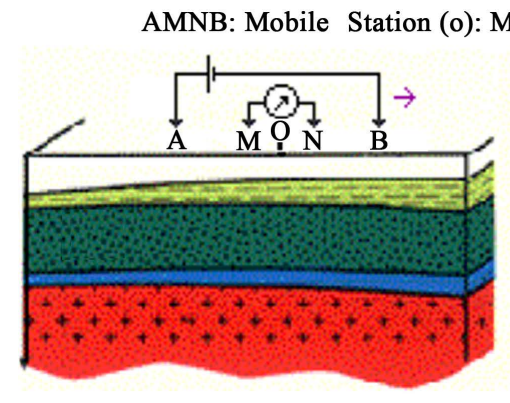

(a)

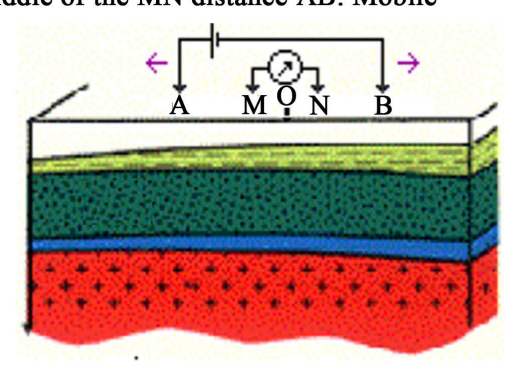

(b)

Figure 3. (a) Schlumberger electrical profiling; (b) Schlumberger electrical sounding. 
We used the direct current resistivimeter, Syscal Junior 48 (IRIS Instrument) system. This unit runs under the Rho mode which enables to measure the resistivity (Rho) of ground structures. Acquisition of electrical data (sounding and profiling) is made using the Schlumberger direct method where the current is injected through A and B electrodes (Figure 3) and the potential difference is measured through receiving electrodes $\mathrm{M}$ and N [17].

The apparent resistivity data from Schlumberger electrical profiles were processed and modelled using the Geotomo Res2Dinv software [14] [18] to obtain pseudosections or inverse pseudosections that reflect the true resistivity values of local subsurface structures. The electrical soundings were interpreted using WinSev from Geosoft [19] which permits to obtain the depth distribution of layers at each station, hence enabling to plot geological sections. Resistivity maps were plotted using Surfer software [20] which determines the spatial distribution of resistivity by interpolating their values in the area under study.

\section{Results}

\subsection{Pseudo-Sections}

Electrical sections of profiles L1 to L6 (Figures 4(a)-(c) and Figures 5(a)-(c)) were plotted with Res2Dinv [21]. These figures reveal an approximate investigation depth of $128 \mathrm{~m}$ for each profile. This depth corresponds to the maximum cable length $(\mathrm{AB}=600 \mathrm{~m})$ according to $\mathbf{x}_{l}$ position along a profile [16] [22] .

For the L1 profile (Figure 4(a)), the resistivity is slightly low (Rho $<1500 \Omega \cdot \mathrm{m}$ ) from near subsurface to about $40 \mathrm{~m}$ depth in the eastern part and less than $20 \mathrm{~m}$ in the western part. Downward along E-W, one notices a bedding of layers and an increase of resistivity values above $10,000 \Omega \cdot \mathrm{m}$. These resistive and bedded layers suggest unweathered granitic structures [23]. Along the profile $\left(1100<\mathbf{x}_{l}<1900 \mathrm{~m}\right)$, the resistivity is fairly low $(\mathrm{Rho}<2500 \Omega \cdot \mathrm{m})$ and iso-resistivity lines are nearly subvertical. Low resistivity values and the shape of iso-re-

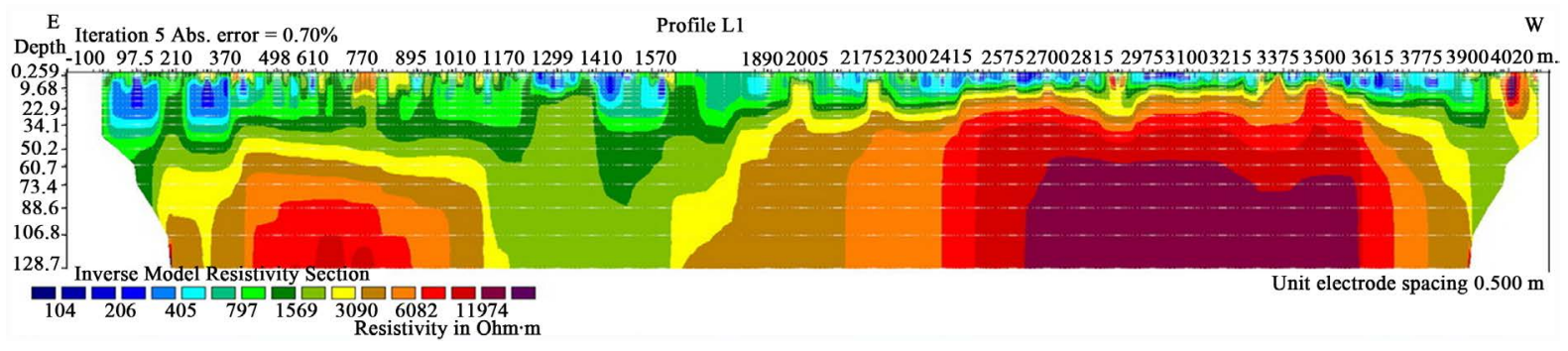

(a)

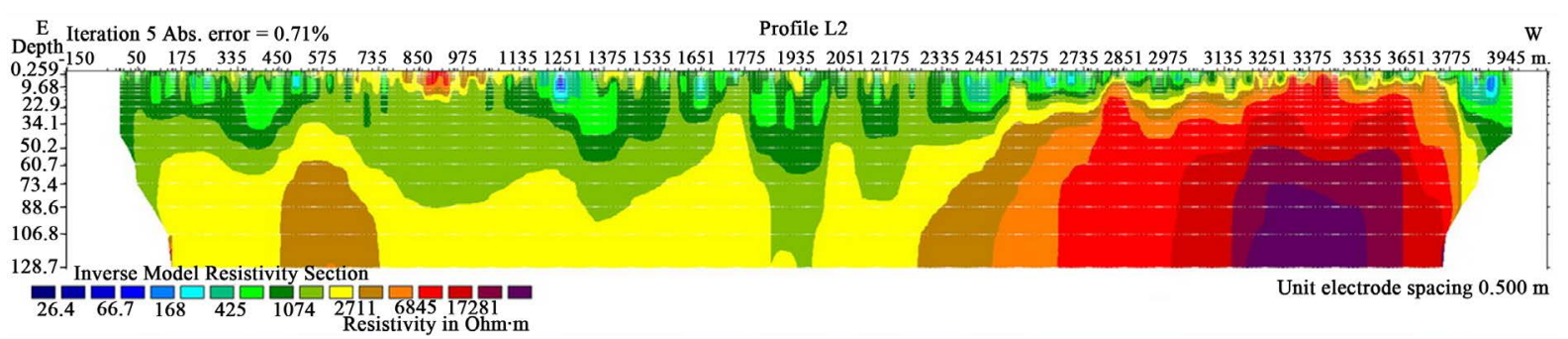

(b)

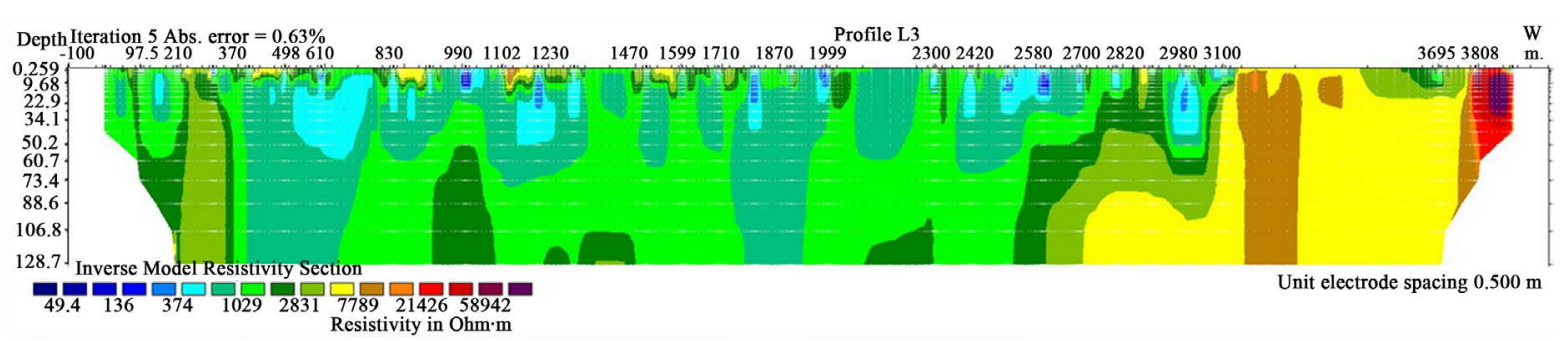

(c)

Figure 4. (a) Pseudo-section of apparent resistivity of Profile L1; (b) Pseudo-section of apparent resistivity of Profile L2; (c) Pseudo-section of apparent resistivity of Profile L3. 


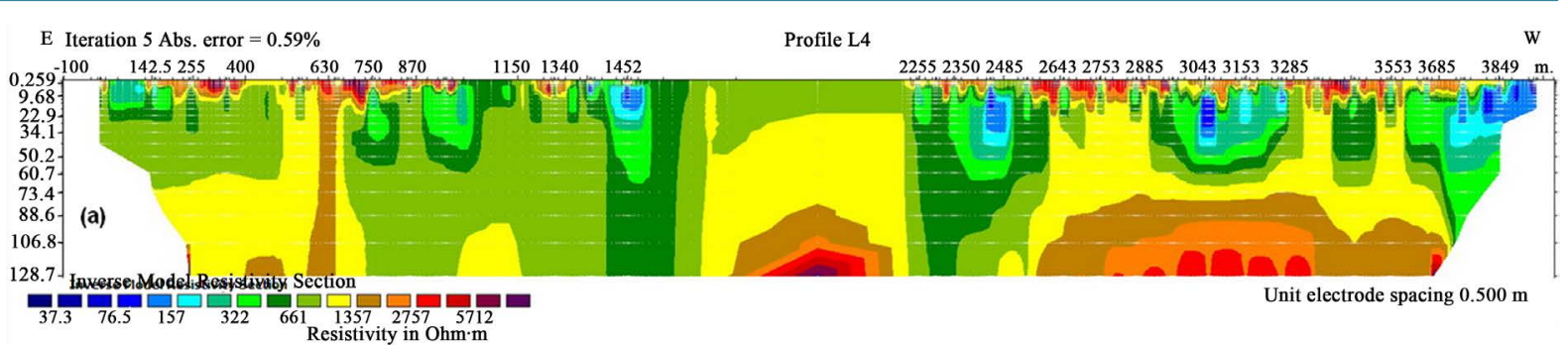

(a)

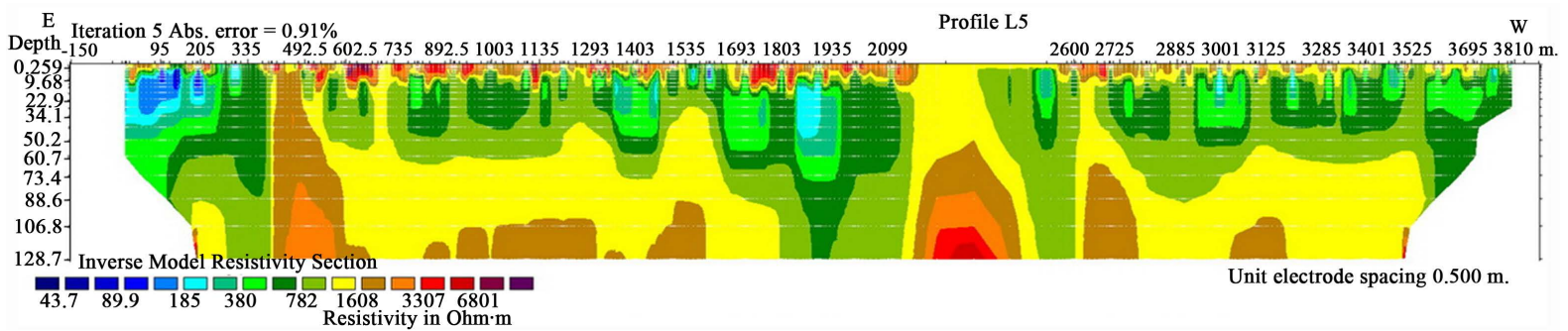

(b)

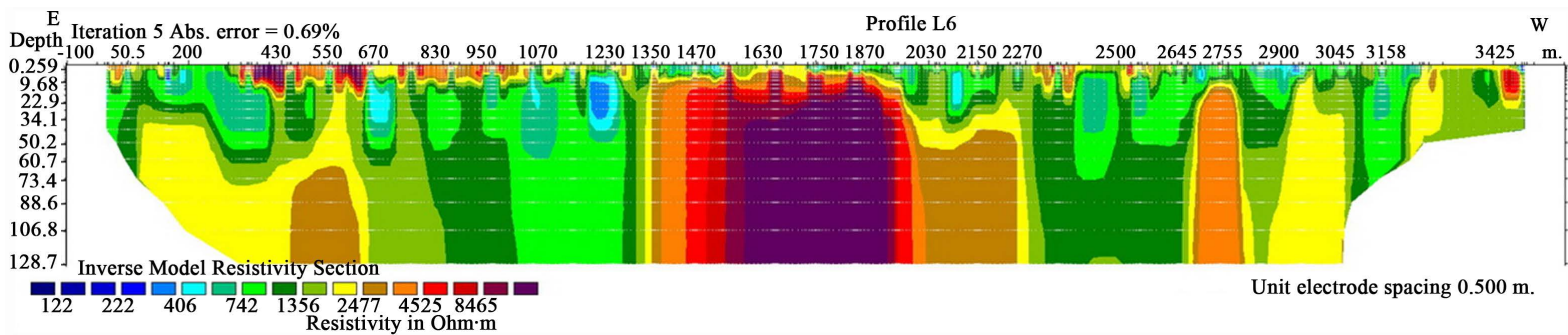

(c)

Figure 5. (a) Pseudo-section of apparent resistivity of Profile L4; (b) Pseudo-section of apparent resistivity of Profile L5; (c) Pseudo-section of apparent resistivity of Profile L6.

sistivity curves are significant to a weakness zone or conductive discontinuity. It may exhibit a fracture, a fault or a shear zone along the profile [16] [22] [23].

N-oriented, profiles L2 and L3 (Figure 2 and Figures 4(b)-(c)) clearly highlight a strong resistivity contrast. The western part of the area under study $\left(0<\mathbf{x}_{\boldsymbol{l}}<2100 \mathrm{~m}\right)$ is generally low resistive (Rho $\left.<2500 \Omega \cdot \mathrm{m}\right)$. The $\boldsymbol{x}_{\boldsymbol{I}}$ width increases progressively from profile L2 to profile L3. The electrical responses of these profiles (L2 and L3) look like resistive bedded layers (Rho $>3000 \Omega \cdot \mathrm{m}$ ) in the eastern side $\left(2500<\mathbf{x}_{l}<3800 \mathrm{~m}\right.$ and $\mathbf{x}_{l}>3000 \mathrm{~m}$ ). Effects of these layers go downward to deep structures and they are evidences of fresh granitic structures which sometimes outcrop [22] [23]. The bedding and the resistance of layers disappear at the west; and a weakness, an accumulation or infiltrations' zone sets itself progressively. Thus, in some parts of the area, there are resistive shallow deposits (Rho $>3000 \Omega \cdot \mathrm{m}$ ) which may be laterite layer [24].

Along profiles L4 and L5 (Figures 5(a)-(b)) deep structures are low resistive. They are bounded top and down by more resistive structures. This structural geoelectrical morphology characterizes an accumulation zone of weathered structures or a fluids' infiltration zone [22] [23]. Meanwhile around $630 \mathrm{~m}$ and $450 \mathrm{~m}$ along profiles L4 and L5 respectively, an involvement of deep resistive materials on surface characterized by conic domes (Figures 5(a)-(b)) is observed.

On profile L6 (Figure 5(c)), granitic structures characterized by high resistivity values (Rho $>3000 \Omega \cdot \mathrm{m}$ ) cover the centre $\left(1250<\mathbf{x}_{l}<2250 \mathrm{~m}\right)$. Weakness zones or discontinuities zones characterized by low resistivity values $($ Rho $<2500 \Omega \cdot \mathrm{m})$ cover the two ends of the profile $\left(0<\mathbf{x}_{l}<1250 \mathrm{~m}\right)$ and $\left(1250<\mathbf{x}_{l}<3500 \mathrm{~m}\right)$.

\subsection{Resistivity Map}

The Figure 6 represents the space distributions of the resistivity computed by the surfer software for three depth 


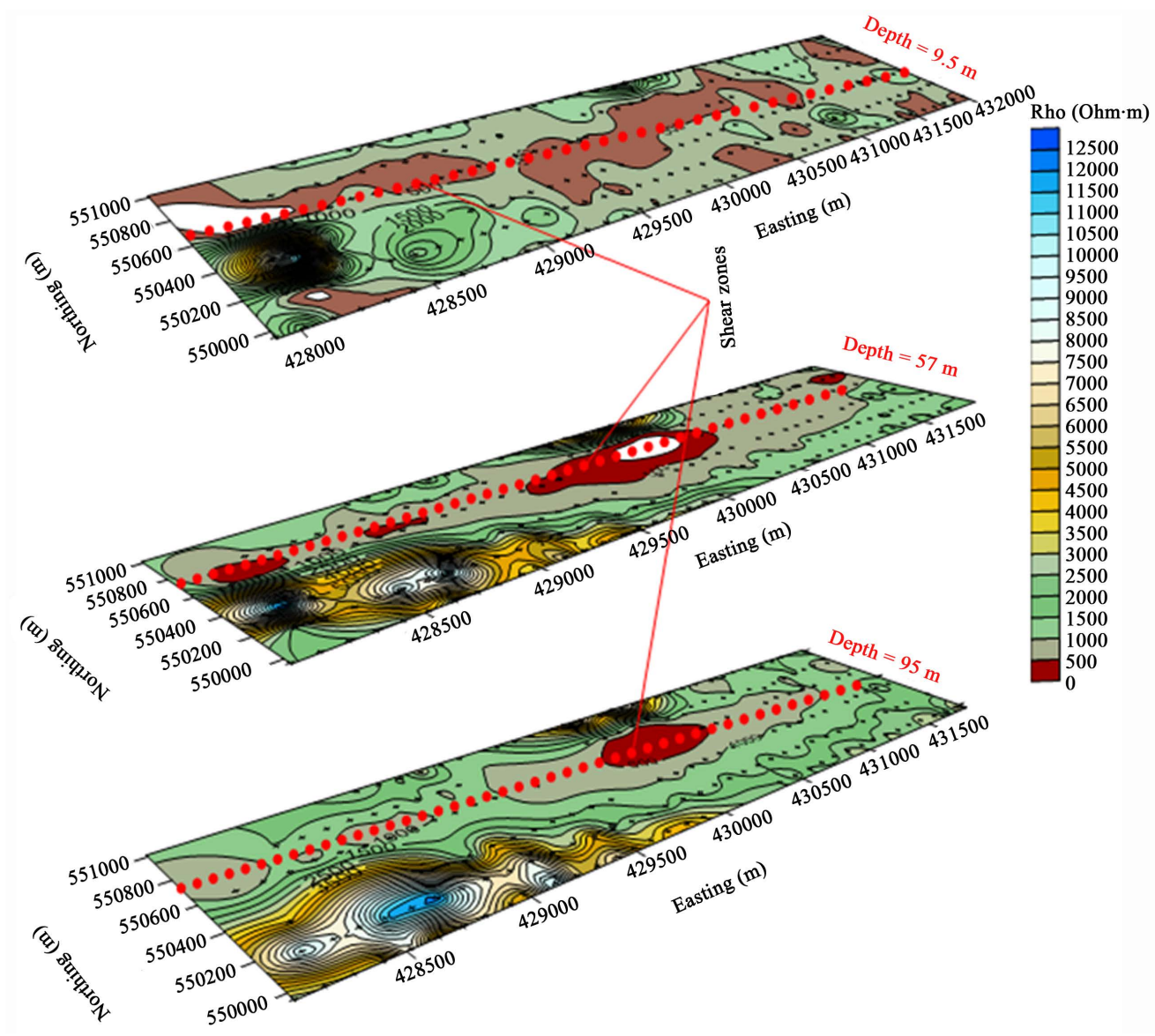

Figure 6. Resistivity maps of $\mathrm{AB}=50 \mathrm{~m}, \mathrm{AB}=300 \mathrm{~m}$ and $\mathrm{AB}=500 \mathrm{~m}$.

levels corresponding to the three arrays used: $\mathrm{AB}=50 \mathrm{~m}$ and $\mathrm{MN}=5 \mathrm{~m}, \mathrm{AB}=300 \mathrm{~m}$ and $\mathrm{MN}=30 \mathrm{~m}, \mathrm{AB}=$ $500 \mathrm{~m}$ and $\mathrm{MN}=50 \mathrm{~m}$. These arrays represent depths $9.5 \mathrm{~m}, 57 \mathrm{~m}$ and $95 \mathrm{~m}$ respectively [16].

In the centre of the study area and along the E-W direction, resistivity maps highlight (Figure 6) a conductive discontinuity characterized by low resistivity values (Rho $<1500 \Omega \cdot \mathrm{m}$ ). The extension of this area decreases to deep structures (Figure 6). It is located at boundaries of resistive zones characterized by high resistivity values (Rho $>2500 \Omega \cdot \mathrm{m}$ ) and narrowing of iso-resistivity curves. This curves' narrowing prove an inner to outer variation of geological structures along the N-S trend. Central structures materialize decayed rocks, accumulation or infiltration structures [11] [22]. They show up the presence of weakness zones in the central part of the study area [11] [22]. Otherwise resistive structures bounding these zones characterize fresh granitic formations [25].

\subsection{Geological Section}

The interpretations of electrical sounding curves from the study area and geological surveys have permitted to realize the geological sections [26] of the subsurface crossed by profiles L2 and L4 (Figure 7 and Figure 8). These geological sections quantitatively illustrate the geology of the area. East of profile L2 geological section, the geological profiling shows a four layered model structure (Figure 7). The superficial layer or topsoil lies on a lateritic cover with a variable thickness which remains less than $10 \mathrm{~m}$ (Figure 7). The third layer corresponds to a weathered or conductive layer. It lies on the basement. To the western part of profile L2 geological section, the geological profiling shows three layers (Figure 7). The superficial layer or topsoil lies on the slightly thick weathered granite. The third layer represents the rocky or granitic basement. The geological section of profile L4 (Figure 8) is similar to the eastern part of profile L2 geological section. The weathered layers or conductive layers evidenced by geological sections permits to highlight tectonic unevenness of the previous results [8] [9] [22] [25]. 


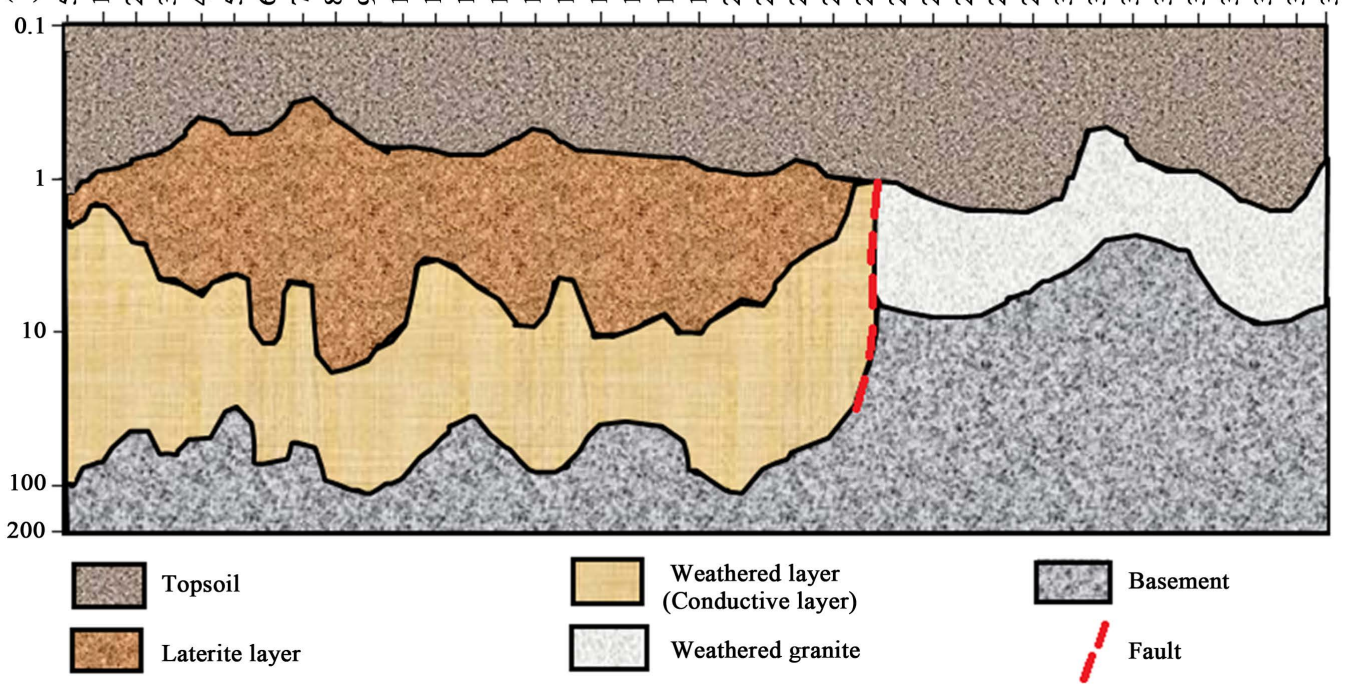

Figure 7. Geological section along of the profile L2.

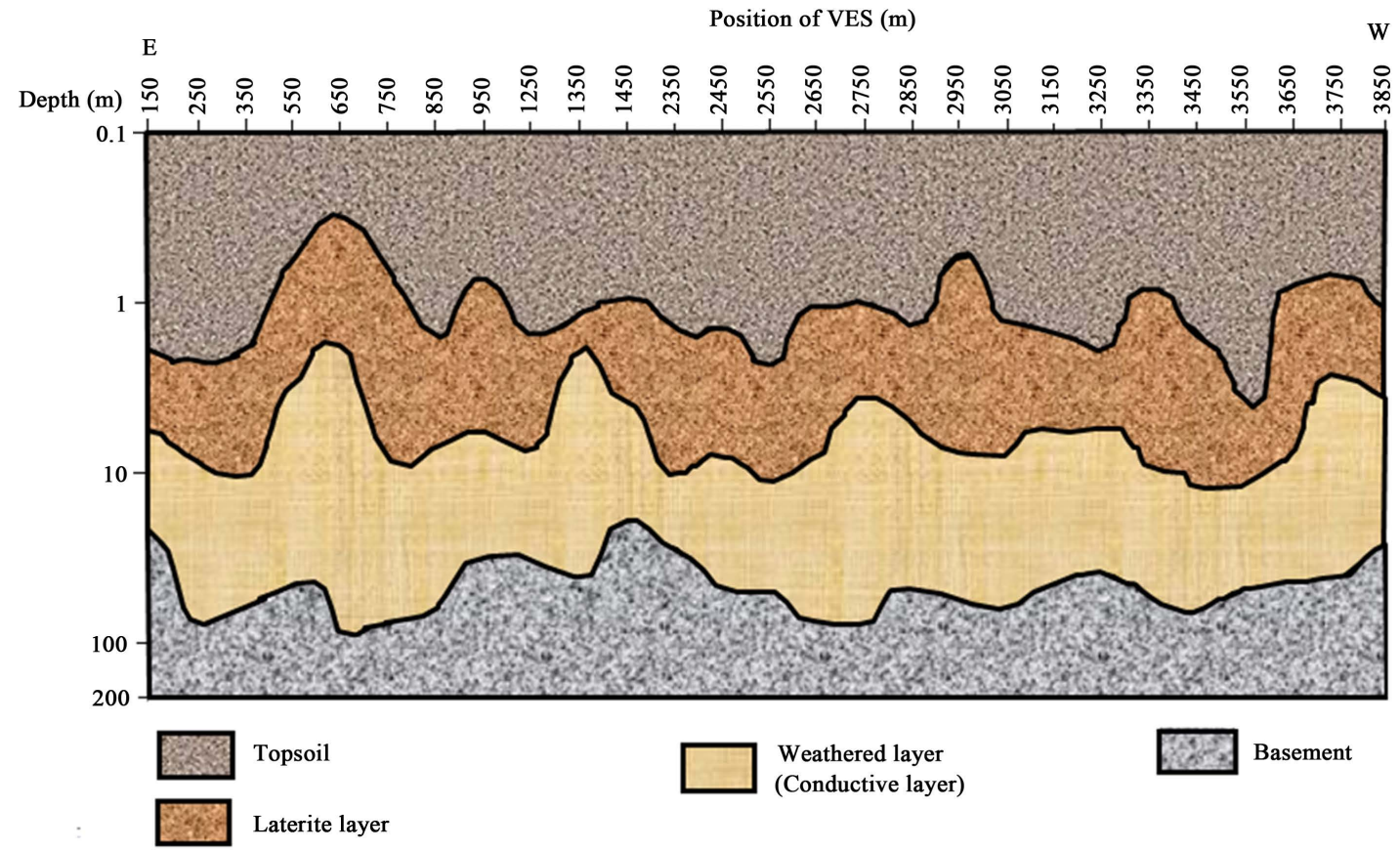

Figure 8. Geological section along of the profile L4.

\section{Discussion}

The analyses of resistivity variations through pseudo-sections provide quantitative and qualitative information upon the conductivity of the studied area's subsurface. During these analyses, we have delineated two different geological zones [27] [28]:

- The first zone is characterized by high resistive bedded structures. It fits the geological background of fresh granitic structures which sometimes outcrop [11].

- The second zone is characterized by low resistive structures. It fits the weakness zones or conductive zones [23]. These conductive zones or conductive discontinuities characterize clay minerals intrusions inside bar- 
ren structures of the granitic basement which underwent shearing and weathering process of shallow struc-

tures [11].

The tectonic setting of the study area enables to match that tectonic unevenness with shear zones. There, fluids infiltration's ability is considerable, thus increasing the weathering ability of in situ metamorphic or magmatic structures [25].

In addition, analyses of the resistivity variations through resistivity map show that the space distributions of resistivity, for each subsurface level, are not uniform. The resistivity contrasts highlight weakness zones or fluids' infiltration zones within granitic structures [29] [30]. These weakness zones considered as tectonic unevenness also characterize shear zones with a high accumulation capability of in situ weathered or dissolved structures [22]. They are located at the middle of the study area and have an E-W strike. The mineralization characterized by conductive zones is located in shear zones [25] [28]. It reflects the presence of disseminated clay minerals [22] [27] [29].

In the mining and hydrogeological researches, weathered layers or conductive layers (Figure 7 and Figure 8) characterize the target zones [31]. They are identified as mineralogical deposits and groundwater zones for the mining and hydrogeological researches respectively [22] [24] [26]. We suggest that conductive layers may represent target zones of clay minerals concentrations [28]-[30]. The gold washing activity exerted along stream banks in the area [32] [33] suggest these are gold bearing structures located in weathered quartz veins [34].

\section{Conclusion}

The electrical Schlumberger data acquisition (sounding and profiling) in the Tindikala-Boutou area along the Kadey River, using Direct Current (DC) method, has permitted to identify the tectonic unevenness and to characterize its mineralogical nature. Results which enabled this identification come from pseudo-sections of resistivity and the resistivity maps particularly. Interpretations made from different models are able to highlight weakness zones or conductive zones which characterize shear zones following an E-W strike. In these zones, the geological sections bring out weathered layers or conductive layers which constitute the target zones for mining and hydrogeological researches. According to the geological and tectonic background of the study area, clay minerals have been identified as the associated mineralization along shear zones within the Precambrian granitic basement. The presence of gold washers attests the existence of gold bearing clay mineralized structures disseminated in weathered quartz veins along the Kadey River.

\section{Acknowledgements}

The authors are grateful to the reviewers for their kind remarks making the manuscript clearer and more pertinent. The authors are also grateful to the Artisanal and Small Scale Unit of the Ministry of Mines, Industry \& Technological Development for providing the Syscal Current Iris instrument to collect the data sets on site.

\section{References}

[1] Cornachia, M. and Dars, R. (1983) Un trait majeur du continent africain. Les Linéaments centrafricains du Cameroun au Golfe d'Aden. Bulletin de la Societe Geologique de France, 7, 102-109.

[2] Rolin, P. (1995) La zone de décrochement panafricain des Oubanguides en République Centrafricaine. Comptes Rendus de l'Académie des Sciences-Series I, Paris, 320, 63-69.

[3] Mvondo, H., Den-Brok, S.W.J. and Mvondo-Ondoa, J. (2003) Evidence for Symmetric Extension and Exhumation of the Yaoundé Nappe (Pan-African Fold Belt, Cameroon). Journal of African Earth Sciences, 35, 215-231. http://dx.doi.org/10.1016/S0899-5362(03)00017-4

[4] Mvondo, H., Owona, S., Mvondo-Ondoa, J. and Essono, J. (2007) Tectonic Evolution of the Yaoundé Segment of the Neoproterozoic Central African Orogenic Belt in Southern Cameroon. Canadian Journal of Earth Sciences, 44, 433444. http://dx.doi.org/10.1139/e06-107

[5] Olinga, J.B., Mpesse, J.E., Minyem, D., Ngako, V., Ndougsa-Mbarga, T. and Ekodeck, G.E. (2010) The Awaé-Ayos Strike-Slip Shear Zones (Southern-Cameroon): Geometry, Kinematics and Significance in the Late Panafrican Tectonics. Neues Jahrbuch für Geologie und Paläontologie-Abhandlungen, 257, 1-11. http://dx.doi.org/10.1127/0077-7749/2010/0042

[6] Regnoult, J.M. (1986) Synthèse géologique du Cameroun. DMG/MINMEE, 119 p.

[7] Gazel, J. and Giraudie, C. (1965) Notice explicative sur la region Abong-Mbang Ouest et Batourie de la carte géologique 
de reconnaissance. Mémoire du BRGM, No 92, Direction des Mines et Géologie, Yaoundé, Cameroun, 29 p.

[8] Meying, A., Ndougsa Mbarga, T. and Manguelle-Dicoum, E. (2009) Evidence of Fractures from the Image of the Subsurface in the Akojolinga-Ayos Area (Cameroon) by Combining the Classical and the Bostick Approaches in the Interpretation of Audio-Magnetotelluric Data. Journal of Geology and Mining Research, 1, 159-171.

[9] Mbom-Abane, S. (1997) Investigation géophysique en bordure du Craton du Congo (région d’Abong-Mbang/Akonolinga, Cameroun) et implications structurales. Thèse Doctorat d’Etat ès Sciences, Université de Yaoundé I, 187.

[10] Ndougsa-Mbarga, T., Meying, A., Bisso, D., Layu, D.Y., Sharma, K.K. and Manguelle-Dicoum, E. (2011) Audiomagnetotellurics (AMT) Soundings Based on the Bostick Approach and Evidence of Tectonic Features along the Northern Edge of the Congo Craton, in the Messamena/Abong-Mbang Area (Cameroon). Journal of Indian Geophysical Union, 15, 145-159.

[11] Parasnis, D.S. (1997) Principles of Applied Geophysics. 5th Edition, Chapman and Hall, London, 104-176.

[12] Keary, P. and Brooks, M. (1991) An Introduction to Geophysical Exploration. 2nd Edition, Blackwell Scientific Publications, Oxford, 254 p.

[13] Ward, S.H. (1990) Resistivity and Induced Polarization Methods. In: Ward, S.H., Ed., Geotechnical and Environmental Geophysics, Society of Exploration Geophysicists, Tulsa, 147-190.

[14] Loke, M.H. (1994) The Inversion of Two Dimensional Resistivity Data. PhD Thesis, University of Birmingham, Birmingham, 122.

[15] Chapellier, D. (2000) Prospection électrique en surface. Cours de géophysique, Université de Lausanne, Institut Français de Pétrole, 98 p.

[16] Loke, M.H. (2000) Electrical Imaging Surveys for Environmental and Engineering Studies: A Practical Guide to 2-D and 3-D Surveys. 61.

[17] Burger, R.H., Sheehan, F.A. and Jones, C.H. (2006) Introduction to Applied Geophysics: Exploring the Shallow Subsurface, W.W. Norton \& Company, Inc., New York, 265-347.

[18] Loke, M.H. and Barker, R.D. (1996) Rapid Least-Squares Inversion of Apparent Resistivity Pseudosections by a Quasi-Newton Method. Geophysical Prospecting, 44, 131-152. http://dx.doi.org/10.1111/j.1365-2478.1996.tb00142.x

[19] Jenny, J. and Borreguero, M. (1999) Winsev 5, 1-D Inversion Software.

[20] Surfer. Version 7.00, Surface Mapping System Copyright (C 1993-1999. Golden Software, Inc., Colorado.

[21] Res2Dinv ver. 3.59 for Windows XP/Vista/7 (2010) Rapid 2D Resistivity \& IP Inversion Using the Least-Squares Method. Geoelectrical Imaging 2D \& 3D. GEOTOMO Software, Malaysia.

[22] Meju, M.A. (2002) Geoelectromagnetic Exploration for Natural Resources: Models, Case Studies and Challenges. Surveys in Geophysics, 23, 133-205. http://dx.doi.org/10.1023/A:1015052419222

[23] Ngando, A.M., Nouayou, R., Tabod, T.C. and Manguelle-Dicoum, E. (2011) Evidence for Precambrian Faulting in the Tibati Adamawa Region of Cameroon Using the Audiomagnetotelluric Method. Geofísica Internacional, 50, $129-146$

[24] Egbai, J.C. (2011) Vertical Electrical Sounding for the Investigation of Clay Deposit in Orerokpe, Delta State. Journal of Emerging Trends in Engineering and Applied Sciences, 2, 260-265.

[25] Gouet, D.H., Ndougsa-Mbarga, T., Meying, A., Assembe, S.P. and Man-Mvele Pepogo, A.D. (2013) Gold Mineralization Channels Identification in the Tindikala-Boutou Area (Eastern-Cameroon) Using Geoelectrical (DC \& IP) Methods: A Case Study. International Journal of Geosciences, 4, 643-655. http://dx.doi.org/10.4236/ijg.2013.43059

[26] Coker, J.O. (2012) Vertical Electrical Sounding (VES) Methods to Delineate Potential Groundwater Aquifers in Akobo Area, Ibadan, South-western, Nigeria. Journal of Geology and Mining Research, 4, 35-42.

[27] Salmirinne, H. and Turunen, P. (2007) Ground Geophysical Characteristics of Gold Targets in the Central Lapland Greenstone Belt. Geological Survey of Finland, Special, 44, 209-223.

[28] Holliday, J.R. and Cooke, D.R. (2007) Advances in Geological Models and Exploration Methods for Copper \pm Gold Porphyry Deposits. Ore Deposits and Exploration Technology, 53, 791-809.

[29] Lowrie, W. (2007) Fundamentals of Geophysics. 2nd Edition, Cambridge University Press, Cambridge, 381. http://dx.doi.org/10.1017/CBO9780511807107

[30] Tijani, M.N., Osinowo, O.O. and Ogedengbe, O. (2009) Mapping of Sub-Surface Fracture Systems Using Integrated Electrical Resistivity Profiling and VLF-EM Methods: A Case Study of Suspected Gold Mineralization. RMZ Materials and Geoenvironment, 56, 415-436.

[31] Campbell, D.L. and Fitterman, D.V. (2000) Geoelectrical Methods for Investigating Mine Dumps. Proceedings of the 5 th International Conference on Acid Rock Drainage (ICARD 2000), Denver, Colo, 2, Society for Mining, Metallurgy, and Exploration, Inc., Littleton, 1513-1523. 
[32] Kim, S., Yoon, M.J., Kim, S.G. and Kwon, D.J. (2009) Exploration Report Colomine Placer Gold Project Cameroon. Geotech Consultant Co., Ltd., Seoul, 87.

[33] Vairon, J., Edimo, A., Simeon, Y. and Vadala, P. (1986) Protocole d'accord pour la Recherche des minéralisations d'or dans la province aurifère de l'Est Cameroun. Rapport du BRGM. Mission Or Batouri, deuxième et troisième phase, $251 \mathrm{p}$.

[34] Biste, M.H., Bufler, R. and Friedrich, G. (1991) Geology and Exploration of Gold Placer Deposits the Precambrian Shield of Eastern Bolivia. In: Dpjdp-Dtcd, O., Ed., International Symposium on Alluvial Gold Placers, La Paz, 148158. 